IRSTI 68.75.55

UDC 330.3

https://doi.org/10.51579/1563-2415.2021-1.12

\title{
UPDATING THE AGRO-INDUSTRIAL COMPLEX SYSTEM IN THE CONTEXT OF THE REFORM S. Kuashbay ${ }^{* 1}$, G. I. Abdikerimova ${ }^{2}$, J. K. Turebayeva ${ }^{3}$, D.P. Jazdykbayeva ${ }^{4}$ \\ ${ }^{1,2,3}$ Shymkent University, Shymkent, Kazakhstan \\ ${ }^{4}$ Mardan Saparbayev Institute, Shymkent, Kazakhstan \\ e-mail: turebaevaz@mail.ru
}

Summary. The research is devoted to the issues of active development of the agro-industrial complex in Kazakhstan within the framework of modern reform.

Originality of the research. The updated structure of the resource management system of the agro-industrial complex of Kazakhstan is proposed, the subsystems and blocks included in it, their content and measures for formation are defined.

Research result. The prospects for the development of the agro-industrial complex and methods for achieving the goals of the government of Kazakhstan are presented. Effective work of the agro-industrial sector of the economy of Kazakhstan is possible only with active state support at the national and regional levels.

Keywords: agro-industrial complex, economic actualization, efficiency, competitiveness.

Basic provisions. The features of the formation of the system of state regulation of Kazakhstan's agriculture in the market conditions determined by the imperatives of the state agrarian policy (ensuring socially fair agricultural relations, preserving the national natural wealth and food security of the country), the specifics of natural, human and material resources and the inability of most agricultural enterprises to self-regulate and expand reproduction are determined.

Introduction. Improvement of the system of state regulation and support of agriculture now has to be carried out in the new macroeconomic conditions. They clearly show that expressions such as «agriculture is the engine of the entire economy» or «the agricultural sector is the driver of growth in modern conditions» are incorrect. It is quite obvious that the current locomotive of the economy of the Republic of Kazakhstan is still the fuel and energy complex.

The price of oil and gas and revenues from their sale significantly affect the dynamics of the gross domestic product, the state of the budget, and changes in household incomes.

And agriculture, its condition and growth opportunities depend on the overall macroeconomic situation.

The agricultural sector in favorable natural and climatic conditions years is actually not a driver of growth, but a «damper», «shock absorber» of the economy in a recession. Under adverse weather conditions, the agricultural sector even worsens the situation [1].

In addition, the situation is aggravated by the fact that in fact the lion's share of support falls on the Federal budget, since the regions have a very tense budget situation. Therefore, we have to choose the areas of support among all areas.

Economic resources are diverted to many other areas (re-equipping the army, fighting terrorism). These are prerequisites and conditions that should be taken into account when considering issues of support for the agricultural sector of the economy.

Materials and methods. One of the most important sectors of the economy of any country is the agroindustrial complex, which produces the necessary food for society. Effective development of the agro-industrial sector largely determines the level of food security of the state, the state of the entire potential of the national economy, as well as the social and economic situation in the country as a whole.

The methodological basis of the research is based on General scientific methods of cognition-deduction and induction, analysis and synthesis, content-media analysis, sociography, system and comparative-historical methods that allow us to identify the Genesis, sequence and functioning of the stages of digitalization in the agricultural sector.

Results and discussion. Kazakhstan is an agro-industrial country where agriculture is the sphere of life of the main part of the population. Today, forty-three percent of the population lives in rural areas, and the level of development of agricultural production largely determines the standard of living not only for those who work here, but also for those who are more or less connected with this market. The level of development of agricultural production is closely linked to the welfare of the majority of Kazakhstanis.

Kazakhstan is the largest grain power in the world. In grain-growing areas, mainly strong and hard wheat varieties with a high content of gluten are cultivated, this is the kind of wheat that is in great demand on the world market [2].

Grain crops, in General, cover an area of eighteen million hectares, of which twelve million hectares are reserved for wheat, the gross yield of which is 600,000 tons.

The experience gained in growing grain maize provides a harvest of eighty centners per hectare. Rice, buckwheat, rapeseed, soy, oats, cotton, sugar beet, and many vegetables and fruits are also cultivated in Kazakhstan [3]. 
The traditional branch of agriculture in the Republic of Kazakhstan is animal husbandry, which provides the population with food, and light industry-with raw materials. Every year, Kazakhstan produces up to 750,000 tons of meat, more than four and a half million tons of milk, about two and a half billion eggs, and 30,000 tons of wool.

In Northern regions dominated by pig and dairy cattle in the South and beef cattle breeding, sheep breeding, horse breeding and camel breeding in the Western and Eastern cattle breeding and horse breeding.

Poultry farming is distributed almost evenly across all regions.

For desert and semi-desert areas, the main types of agricultural production are sheep, horse and camel breeding. Sheep breeding develops mainly in four directions: fine-wool, semi-fine-wool, meat-cutting and smushkovoe.

Horse breeding in the Republic of Kazakhstan, which has large areas of natural pastures, is also traditional, since horses are not only a means of transportation, but also a source of food - meat and koumiss [4].

The main camel population is located in Atyrau, Mangistau, Kyzylorda and Turkestan regions.

In the East Kazakhstan region, four farms are engaged in maral breeding. They produce about eight tons of dry antlers annually. In addition, marals provide excellent leather raw materials used for the production of suede.

The products of both livestock and crop production are produced at state, cooperative and joint-stock agricultural enterprises, in peasant and farm farms, as well as in private subsidiary farms.

In accordance with the strategy «Kazakhstan 2050» in the agro-industrial complex, the main directions in the industry are to improve the country's food security, form an agricultural business, increase the competitiveness of domestic products and increase sales volumes, both in the domestic and foreign markets, reduce the level of food imports, and introduce an effective system of state support for agricultural production.

In order to increase productivity in agriculture, to use export potential of the agricultural sector the government of Kazakhstan set the goal of introducing modern technology through foreign investment, provide incentives to investors in the form of a guarantee of return on investment, exemption from certain types of taxes, co-financing. Kazakhstan is introducing insurance forms to support agricultural producers in the event of adverse weather conditions $[5]$.

The next largest producers are individual entrepreneurs and farmers / farmers who cultivate about $30 \%$ of the agricultural land. Farms can be large, medium, or small. As a rule, larger farms are more common in the Northern regions, which may have land plots of more than 5,000 hectares. Medium-sized and small-scale farms are mainly concentrated in the southern regions, where grain, fodder and technical crops, vegetable melons, fruit and berry crops and others are cultivated on irrigated lands. In the southern regions the size of farms can vary from 3 to 500 ha and above.

Personal-subsidiary farms, in fact, are represented by families living in rural areas, in a personal farmstead that has an average of 1 to 3 cows, sheep and goats, poultry, a small vegetable garden, the area of which can vary from a few acres to $0.25-1$ ha. Despite the small scale, LPH currently produces up to $70 \%$ of all livestock products in the country.

In his Message to the people of Kazakhstan, the Head of state K. Tokayev noted that the overall goal in the development of agriculture is to increase labor productivity and exports by 2.5 times. Kazakhstan has a great agricultural potential, which makes it possible to make a real breakthrough in agriculture in the next five years. To do this, first of all, it is necessary to establish work on attracting investment in the agro-industrial complex. The government continues to work on developing clear short-and medium-term priorities for agricultural policy and other support tools.

One of the important issues for the further development of agriculture is the export of agricultural products, which has a huge potential. In total, out of 500 billion tenge planned for export support, 100 billion tenge is provided for agricultural exports. Now more than $60 \%$ of exports of agricultural products are raw materials.

The efficient use of land is also an important issue. An inventory of agricultural land conducted by the Ministry of agriculture revealed 16.5 million hectares of unused land. The government is working to audit all agricultural land and digitize the land cadastre information system. Exports of agricultural products in 2019 increased by $6.4 \%$ in 2019 , exports of agricultural products amounted to 12.41 million tons worth $\$ 3.29$ billion, which is $\$ 198$ million or $6.4 \%$ more than in 2018. At the same time, the share of exports of processed products from the total volume of exports of agricultural products in 2018 was $33.65 \%$. The planned indicators of the state program for the development of the agro-industrial complex for the export of agricultural products were exceeded by $24.1 \%$. Last year, 551 types of agricultural products were exported to 72 countries.

It should be noted that more than $50.2 \%$ of the export product range is accounted for processed agricultural products.

The expansion of the list of exports of processed products is the result of the policy of diversification of agricultural production and development of processing. The plan to attract investment in the agro-industrial complex for 2020 is 559 billion tenge with the implementation of 94 investment projects. Including 16 projects with foreign participation, which are currently under development and implementation in the amount of $\$ 837$ million.

Promising investment projects include the construction of a meat processing plant with the participation of a large American multinational company in the field of meat processing «Tyson Foods Inc.» and the construction of a 
plant for the production of modern irrigation systems «Valmont Industries» (USA) [6]. Agreements were signed on both projects at the level of the government of the Republic of Kazakhstan [7].

Last year was an extreme year for some regions of our country. The established abnormal heat in July and August was replaced by prolonged rains, which eventually affected both the volume of the harvest and its quality.

In General, most major agricultural crops show moderate growth in production and yield.

In 2020, it is planned to place agricultural crops on an area of 22.5 million hectares, which is more than the level of 2019 by 240 thousand hectares.the area of oilseeds, fodder, vegetable and melon crops and potatoes Will be increased. Last year, the area under buckwheat was reduced by 29.4 thousand compared to 2018 .

A sharp reduction was observed in East Kazakhstan (by 11.7 thousand hectares), Pavlodar (by 9.2 thousand hectares), Kostanay (by 7 thousand hectares) regions. This played on the cost of buckwheat, for which there was an increase in prices in all regions. In this regard, in 2020, the area of this cereal crop will be increased due to its social significance.

There is an acute issue with the use of fertilizers. It is necessary to have an agrochemical cartogram, and it is necessary to step up work on conducting agrochemical analyses of soils.

It is planned to build new agrochemical laboratories, so laboratories equipped with modern automated equipment have already been launched in Kostanay and Petropavlovsk.

Also, one of the most pressing problems is the fight not only against infestation of fields, but also pests and diseases. Timely detection of distribution centers and chemical treatments will prevent significant losses of the crop and its quality. Every year, huge budget funds are allocated to fight them, and the effect is minimal.

The variety of soil-climatic, socio-economic conditions, historically developed location and specialization of agricultural production by natural and economic zones cause a significant differentiation of the levels of development of the agro-industrial complex of Kazakhstan's regions and require taking into account their features when developing a strategy for the development of this important sector of the country's economy.

At the same time, the strategy for the development of the regional agro-industrial complex should first of all be focused on more fully satisfying the effective demand for products of the agricultural sector of the economy through the rational use of production potential, which largely ensures the sustainability of agricultural production and food supply to the region with agricultural products, raw materials and food.

Analysis of competitive advantages of agricultural enterprises gives grounds to assert that, because of the different kinds of objective reasons they have traditionally been in a disadvantageous economic conditions:

- a significant part of agricultural products is perishable;

- the increase in prices for manufactured products is largely limited by its effective demand;

- the product range is monotonous, which increases competition within the industry;

- Strategic development of the crop production industry should include: preservation and reproduction of soil fertility as the main means of production and national heritage of each region; increasing crop yields (area, seeds, fertilizers, etc.);

- increasing the technical and technological level of development of the agro-industrial complex in each region.

The strategic development of the livestock industry should be based on: the development of livestock industries through the reconstruction of existing and the creation of new types of complexes that provide a closed mode of operation; priority development of dairy and meat cattle breeding.

The main measures for improving and modernizing the agro-industrial complex include: for modernization, which requires large expenditures, it is necessary to attract both public and private funds; the main source of funding can be a state program; the introduction of innovations should be carried out in stages, that is, increasing production capacity, reducing the cost of production, saving material costs of production gradually, as preparatory work is underway to introduce innovations; organization of the innovation implementation process.

Kazakhstan's economy is currently going through a difficult stage of its development.

A distinctive feature of the modern period of development of the agro-industrial complex is the fact that agricultural transformations are carried out mainly in the regions. Commercial products are produced here, and direct economic relations between agricultural producers are carried out Regions enter into economic relations not only with each other, but also with foreign countries.

For the normal development of entrepreneurship in rural areas and the effective development of the food market, a special economic mechanism is needed that regulates the development of agricultural production in the region, is able to withstand the impact of negative factors, and is sensitive to the changing market situation. At the same time, the economic mechanism of managing the agro-industrial complex of regions should be built in full accordance with the macroeconomic economic mechanism, but its elements can be supplemented and detailed depending on the territorial, demographic and socio-economic specifics of the region. This is especially important for enterprises where the regional factor is essential. 
The introduction of an effective economic management mechanism is a crucial factor in bringing the agroindustrial complex out of crisis. The ongoing agrarian reform should include the formation and development of both theoretical and practical approaches to improving the agro-industrial complex.

The economic mechanism of management is a part of the economic mechanism, which acts as a way of functioning of the economy as a whole. The economic mechanism of management is more concerned with the functioning of enterprises directly and includes such elements as: planning, financing, commercial economic calculation, pricing, incentive system, analysis, control and accounting system, etc.

By making maximum use of the bio-potential of soil, plants, and animals, organic agriculture can minimize environmental, social, and economic risks, as well as provide opportunities for rural residents to increase their income and improve their quality of life.

The production of eco-products for Kazakhstan farmers is promising, but not yet developed enough, which opens up new opportunities for them. This is an innovative direction and one of its tasks is to preserve local traditions and culture, as well as use the positive experience of farming inherited from older generations.

Production and sale of organic agricultural products is an objective national competitive advantage of the agro-industrial complex of Kazakhstan.

The law «On organic production» provides for the rejection of pesticides, synthetic fertilizers, growth regulators, artificial food additives and prohibits using GMO.

Obtaining organic products is accompanied by maintaining and improving the health of the soil and natural ecosystems, minimizes the threats associated with the instability of development, and creates conditions for the health and well-being of the population.

The total volume of guaranteed water resources is 23.2 cubic meters per year, with the exception of those necessary for use for environmental purposes, ensuring mandatory flow to neighboring States.

In case of unfavorable climatic and transboundary hydrological situations in the future it is projected to reduce surface runoff in Kazakhstan by 11.4 cubic meters per year by 2040 .

The projected decrease in water inflow through transboundary rivers by 2040 is observed in two scenarios: the first - neighboring countries fully choose their limit according to agreements or with equal division of water resources; the second - current trends in increasing water intake by neighboring countries persist, exceeding the established quota. ownership.

In Kazakhstan, there are 643 hydraulic structures that have different departmental affiliation and form of

Due to long-term operation and insufficient volumes of repair and restoration work, the main structures of structures are destroyed, reservoirs are silted up, and a high probability of man-made emergencies is created, especially during spring floods and floods.

The Republic has created the basis for the development of the water industry in the conditions of market relations with the separation of managerial and economic functions, and introduced the basin principle of water resources management.

In normal climatic years, water bodies do not cause any special problems for the population and the country's economy. In extreme or close years, due to the conditions of water flow formation, even watercourses that completely dry up in summer carry the threat of emergency situations.

Floods caused by spring or spring-summer floods are observed on rivers in almost all regions of Kazakhstan. The probability of such situations occurs on the rivers of southern Kazakhstan in February-June, South-Eastern and Eastern Kazakhstan on mountain rivers - in March-July, on lowland rivers - in March-June.

The low-water cycle of water availability also causes significant damage to the country's economy, especially agriculture. In recent years, major water management projects have been implemented to prevent emergencies related to the harmful effects of water, such as the construction of the Koksaray counter-regulator on the Syr Darya river, regulation of the Syr Darya riverbed and the Northern part of the Aral Sea.

\section{References}

1. Rekomendatsii «O soglasovannykh deistviiakh gosudarstv - chlenov Evraziiskogo ekonomicheskogo soiuza v oblasti razvitiia ekonomicheskogo potentsiala selskokhoziaistvennoi produktsii i prodovolstviia») (On the coordinated actions of the Member States of the Eurasian Economic Union in the field of development of the economic potential of agricultural products and food). Evraziiskaia ekonomicheskaia komissiia. M, 2016 g, 13 dekabria, No.30.

2. Gospodarev, A.N. Napravleniia povysheniia konkurentosposobnosti agropromyshlennogo kompleksa gosudarstv Evraziiskogo ekonomicheskogo soiuza (Directions for improving the competitiveness of the agro-industrial complex of the states of the Eurasian Economic Union), Aktualnye problemy menedzhmenta i ekonomiki $v$ Rossii $i$ za rubezhom: sb. nauch. trudov po itogam mezhdunar. nauch.-prakt. konf., Novosibirsk, 2016., pp. 120-122

3. S.T. Zhumasheva, Қаzақstannyң agroonerkasiptik ondirisin damytuga arnalgan arnaiy ekonomikalyg aimagtar (Special economic zones for the development of agro-industrial production in Kazakhstan), S.T.Zhumasheva, B.Sh.Syzdykov, A.S.Abilkasym, Agrarlyқ nаryқ problemalary, 2019, No. 4, pp. 68-76. 
4. A.Zh. Nukesheva, Sotsialnaia infrastruktura selskikh territorii: sostoianie i problem (Social infrastructure of rural areas: state and problems), A.Zh. Nukesheva, Sh.I. Kosymbaeva, S.R. Abdieva, Problemy agrorynka, 2019, No.1, pp. 34-42.

5. G.P. Koptaeva, G.G.Shinet, G.N.Agabekova Agricultural economy: development of crop production and its competitiveness, $N$ e w s of thenational academy of sciences of the republic of Kazakhstan series of social and human sciences ISSN 2224-5294. 170 Volume 5, No. 327 (2019), pp.91 - 102. https://doi.org/10.32014/2019.2224-5294

6. V.N. Seitova, A.N. Isahmetova, A.B. Makhatova, R.Giese The status and the ways of rational use of production capacity of agricultural processing enterprises in the turkestan region, $N$ e $w$ s of the national academy of sciences of the republic of Kazakhstan series of social and human sciences ISSN 2224-5294, Volume 6, No. 328 (2019), pp.5 - 10. https://doi.org/10.32014/2019.2224-5294.201

7. Sakhanova G.B. Prodovolstvennaia bezopasnost Kazakhstana. Vestnik universiteta Turan, 2019 g., No.1, pp. $47-53$

\section{РЕФОРМА КОНТЕКСІНДЕ АГРОӨНЕРКӘСІПТІК КЕШЕН ЖУЙЕСІН ӨЗЕКТЕНДІРУ}

С. Куашбай ${ }^{1}$, Г.И. Абдикеримова ${ }^{2}$, Ж.К. Туребаева ${ }^{3}$, Д.П. Жаздыкбаева

${ }_{1,2,3}$ Шымкент университеті, Шымкент құласы, Қазақстан

${ }^{4}$ Мардан Сапарбаев институты, Шымкент қаласы, Қазақстан e-mail:turebaevaz@mail.ru

Түйін. Қазіргі заманды реформа шенберінде Қазақстанды, агроөнеркәсіптік кешенді белсенді дамыту мәселелеріне арналван зерттеме.

Зерттеудің бірегейлігі. Қазақстанның агроөнеркәсіптік кешенінің ресурстарын басқару жүйесінің өзектілендірілген құрылымы ұсынылды, ован кіретін кіші жүйелер мен блоктар, олардың мазмұны және оларды қалыптастыру жөніндегі шаралар айқындалды.

Зерттеу нәтижелері. Агроөнеркәсіптік кешенді дамыту перспективалары және Қазақстан Үкіметінің қойылган мақсаттарына қол жеткізу ддістері ұсынылган. Қазақстан экономикасының агроөнеркасіптік секторының тиімді жұмысы республикалық және өнірлік дендейлерде белсенді мемлекеттік қолдау кезінде вана мүмкін болады.

Кілт сөздер: агроөнеркәсіптік кешен, экономикалық өзектендіру, тиімділік, басекеге қабілеттілік.

\section{АКТУАЛИЗАЦИЯ СИСТЕМЫ АГРОПРОМЫШЛЕННОГО КОМПЛЕКСА В КОНТЕКСТЕ РЕФОРМЫ \\ С. Куашбай, Г.И. Абдикеримова ${ }^{2}$, Ж.К. Туребаева ${ }^{3}$, Д.П. Жаздыкбаева ${ }^{4}$ \\ ${ }_{1,2,3}$ Шымкентский университет, город Шымкент, Казахстан \\ ${ }^{4}$ Институт Мардана Сапарбаева, город Шымкент, Казахстан e-mail: turebaevaz@mail.ru}

Аннотация. Исследование посвящено вопросам активного развития агропромышленного комплекса, Казахстана, в рамках современной реформы.

Оригинальность исследования. Предложена актуализированная структура системы управления ресурсами агропромышленного комплекса Казахстана, определены входящие в нее подсистемы и блоки, их содержание и меры по формированию.

Результаты исследования. Представлены перспективы развития агропромышленного комплекса $и$ методы достижения поставленных челей правительства Казахстан. Эффективная работа агропромышленного сектора экономики Казахстана возможна только при активной государственной поддержке на республиканском и на региональном уровнях.

Ключевые слова: агропромышленный комплекс, экономическая актуализачия, эффективность, конкурентоспособность. 